\title{
Energirike smoothies til pasienter i sykehjem
}

\section{Helsepersonell erfarer at energirike smoothies ikke alltid virker etter hensikten. Noen pasienter blir obstiperte eller kvalme, og underernærte legger ikke på seg.}

\section{FORFATTERE}

Siv Janne C. Salomonsen

Masterstudent

Det helsevitenskapelige fakultet, Universitetet i Stavanger

\section{Astrid Berland}

Dosent

Avdeling for helsefag, Høgskulen på Vestlandet, Stord/Haugesund

Signe Berit Bentsen

Professor

Det helsevitenskapelige fakultet, Universitetet i Stavanger

\section{NøKKELORD}

Energirike smoothies, Eldre, Sykehjem, Underernæring, Nattfaste

\section{SAMMENDRAG}

Bakgrunn: Eldre pasienter i sykehjem er utsatt for å bli underernærte, og det har vist seg at energirike smoothies kan være et supplement til energirik og næringstett mat for å forebygge og behandle underernæring.

Hensikt: Å utforske hvilke erfaringer helsepersonell hadde med energirike smoothies til eldre pasienter i sykehjem.

Metode: Studien innbefatter tre kvalitative fokusgruppeintervjuer av helsepersonell fra to ulike sykehjem.

Resultat: Enkelte pasienter fikk halsbrann, obstipasjon og kvalme når de hadde inntatt smoothies. Pasienter som var underernærte, gikk ikke opp i vekt, og det er usikkert hvorvidt pasientene inntok mer frukt i tiden de fikk smoothies. Informantene var enige om at smoothies ga pasientene energi, noe som førte til at enkelte ble overaktive. For å få kontroll over inntak av energi, næring og væske er det nødvendig med individuelle nærings- og drikkelister.

Konklusjon: Smoothies kan gi halsbrann, kvalme og forstoppelse, og de som var underernærte, la ikke på seg. Å tilberede individuelt tilpassete smoothies vil bidra til at $\varnothing$ nsker og behov for væske og næringsstoffer blir ivaretatt. 
Underernæring oppstår når inntaket av energi og næringsstoffer ikke dekker ernæringsbehovet, noe som kan medføre at helsetilstanden blir påvirket (1). Ifølge Verdens helseorganisasjon er helse ikke bare fravær av sykdom og skade, men en opplevelse av fysisk, psykisk og sosialt velvære (2). Når det gjelder underernæring hos eldre i sykehjem, varierer forekomsten mellom 10 prosent og 60 prosent $(1,3,4)$.

Det er ulike årsaker til at underernæring oppstår. Én årsak kan være aldringsprosesser, som ofte fører med seg dårlig matlyst og redusert matinntak $(4,5)$. Nattfaste er tiden det går mellom kveldens siste og morgendagens første måltid (6). Tidligere studier viser at nattfaste over elleve timer $\varnothing$ ker risikoen for underernæring og nedsatt kroppsvekt (7). Ulike sykdomsprosesser kan i tillegg føre til økt energibehov og lavt matinntak, som igjen fører til underernæring. Pasienten kan dermed komme i en ond sirkel, med sykdom og påfølgende lavt matinntak, som fører til mer sykdom og lavere matinntak og underernæring $(3,5,8)$.

\section{OVERESTIMERER MATINNTAKET}

Det har vist seg at helsepersonell og pasienten selv overestimerer matinntaket og dermed antar at pasienten har et tilfredsstillende inntak av næringsstoffer (9). Tidligere forskning viser at det er enklere å forebygge underernæring enn å behandle dem som er underernærte (10). Det er som oftest sykepleierne som har hovedansvaret for at eldre i sykehjem får et kosthold tilpasset næringsbehovet, men et tett samarbeid med annet helsepersonell som helsefagarbeidere, lege og ernæringsfysiolog er nødvendig for å sikre et individuelt tilpasset kosthold $(6,9,11,12)$.

\section{«Rutinemessig bruk av energirike smoothies kan være et alternativ for å dekke næringsbehovet.»}

Hyppige måltider og energi- og næringstett mat er noen måter å sikre et tilpasset kosthold på $(5,13,14)$. I tillegg kan rutinemessig bruk av energirike smoothies være et alternativ for å dekke næringsbehovet $(9,15,16)$. Smoothies er en næringsdrikk som består av friske bær, frukt, grønnsaker, juice, sukker, yoghurt eller iskrem, som blir omgjort til puré i en blender $(17,18)$.

En melding til Stortinget i 2012 rettet oppmerksomheten mot det å sikre kostholdet til eldre i sykehjem (19). Videre utarbeidet Helsedirektoratet retningslinjer for å forebygge og behandle underernæring til eldre i sykehjem, der det ble anbefalt energirik kost $i$ kombinasjon med næringsdrikker som smoothies til personer som står i fare for å utvikle underernæring (1). Helsedirektoratet har også stimulert norske kommuner med tilskuddsmidler for å følge kravene i retningslinjene (1).

I denne forbindelsen ble pilotprosjekt «Redusert nattfaste i sykehjem» utprøvd ved to sykehjem i Rogaland i 2014. Målet med pilotprosjektet var å redusere nattfasten samt forebygge og behandle underernæring av eldre pasienter i sykehjem. I forbindelse med pilotprosjektet fikk alle pasientene tilbud om energirike smoothies om kvelden og når de våknet om natten. Basisen i smoothien var meieriprodukter som var rike på protein, fett og karbohydrater, som så ble tilsatt sukker, frukt og bær for å øke inntaket av energi, vitaminer og mineraler (18). Hensikten med denne studien var å utforske hvilke erfaringer helsepersonell hadde med energirike smoothies til eldre pasienter i sykehjem.

\section{METODE}

Studien har en kvalitativ, utforskende tilnærming, og vi utførte tre fokusgruppeintervjuer (20). 


\section{UTVALG}

Vi rekrutterte deltakerne i studien fra to sykehjem i Rogaland, der pilotprosjektet «Redusert nattfaste i sykehjem» ble utprøvd. Fagansvarlig ved sykehjemmene foretok en strategisk utvelgelse (20) av deltakere ut fra følgende inklusjonskriterier: helsepersonell som hadde deltatt i gjennomføringen av pilotprosjektet, og som var >=18 år.

Vi inkluderte til sammen 16 personer blant helsepersonellet. Av disse var det fire som ikke møtte. Utvalget i studien besto derfor av 12 helsepersonellansatte ( 75 prosent). Tabell 1 viser en beskrivelse av deltakerne.

Tabell 1: Karakteristika av informantene som deltok i studien $(n=12)$

\begin{tabular}{lccc} 
& \multicolumn{4}{c}{ Fokusgruppe } \\
Sykehjem & $\mathbf{1}$ & $\mathbf{2}$ & $\mathbf{3}$ \\
\hline $\begin{array}{l}\text { Deltakere (antall) } \\
\text { Kjønn (antall) } \\
\quad \text { Kvinner }\end{array}$ & 3 & Sykehjem 2 & Sykehjem 2 \\
$\begin{array}{l}\text { Alder (år) } \\
\text { Utdanning (antall) }\end{array}$ & 3 & 5 & 4 \\
$\quad$ Sykepleiere & $30-60+$ & $20-60+$ & 4 \\
$\quad$ Vernepleier & - & & $20-50+$ \\
$\quad$ Helsefagarbeidere* & - & 1 & - \\
Ansiennitet i år (gjennomsnittt) & 3 & 2 & - \\
Frafall (antall) & 11 & 7 & 8 \\
& 2 & 2 & 0 \\
\hline
\end{tabular}

* Hjelpepleiere, omsorgsarbeidere, barne- og ungdomsarbeidere

\section{DATAINNSAMLING}

Vi samlet inn data fra tre fokusgruppeintervjuer. Ett av disse intervjuene ble gjennomført ved det ene sykehjemmet og to ved det andre. Intervjuene varte fra 1,5 til 2 timer med førsteforfatter som moderator, og alle intervjuene ble tatt opp på lydbånd. Temaet for gruppediskusjonene var energirike smoothies til eldre i sykehjem. Moderator fors $\varnothing$ kte å utforske informantenes erfaringer med energirike smoothies og stilte oppfølgingsspørsmål underveis der dette var naturlig. Vi la også til rette for at alle skulle komme til orde i diskusjonene, og at alle skulle bli hørt (20).

\section{ETISKE HENSYN}

Før studien ble gjennomført, fikk alle deltakerne skriftlig og muntlig informasjon om studien. Vi informerte også om at all informasjon ble behandlet anonymt og konfidensielt, at deltakelse var frivillig, og at deltakerne kunne trekke seg fra studien når som helst uten begrunnelse. Vi innhentet også tillatelse til å ta samtalene opp på lydbånd. Før studien startet, ga avdelingslederne ved sykehjemmene tillatelse til at vi kunne gjennomføre studien. Studien er godkjent av Norsk samfunnsvitenskapelig datatjeneste (NSD).

\section{ANALYSE}

$\mathrm{Vi}$ analyserte de transkriberte intervjuene i henhold til Graneheim og Lundmans metode for kvalitativ innholdsanalyse (21). Vi utførte analysen i fem steg. I steg 1 leste vi gjennom det transkriberte materialet flere ganger for å få et helhetsinntrykk. I steg 2 identifiserte vi meningsbærende enheter som omhandlet erfaringer helsepersonellet hadde med energirike smoothies til eldre i sykehjem. I steg 3 forkortet vi de meningsbærende enhetene, men beholdt fremdeles kjernen i innholdet i teksten. I steg 4 merket vi de kondenserte meningsenhetene med koder, som ble sammenliknet ut fra likheter og forskjeller. 
Deretter sorterte vi dem i ulike temaer. I steg 5 leste vi teksten innenfor hvert tema grundig. Teksten ble deretter kritisk analysert, sammenliknet og abstrahert, og til slutt formulerte vi fem temaer og seks undertemaer (21). For at analyseprosessen skulle være mest mulig troverdig, diskuterte vi innholdet i teksten - hvordan den kunne forstås og fortolkes (21).

\section{RESULTATER}

Funnene fra analysen av fokusgruppeintervjuene kan oppsummeres i fem temaer, der to av dem har undertemaer:

- individuelle reaksjoner

- fordøyelsesproblemer

- kvalme

- individuell tilpasning

- tilsetting av næringsstoffer

- individuell mat- og drikkeliste

- noen går lei av smoothies

- noen liker smoothies

- mer frukt med smoothies

- de underernærte la ikke på seg

- smoothies gir energi

\section{INDIVIDUELLE REAKSJONER} FORD $\varnothing$ YELSESPROBLEMER

Det kom frem i analysen at enkelte fikk obstipasjon mens andre fikk halsbrann av smoothien. Følgende utsagn illustrerer dette:

«Det sto jo et stort stykke i avisen når vi begynte med dette her, for da sto det at fibrene blir $\emptyset$ delagt i smoothien, men hvis du spiser for eksempel en pære hel, så jobber tarmene mye bedre, så du tenker jo litt på den delen, at på dagtid så får de frukt.»

«En fikk jo halsbrann av det, hun tålte det ikke.»

\section{KVALME}

Noen pasienter ble kvalme av smoothien, men det var usikkert om dette skyldtes sukkeret, fløten eller oljen som ble tilsatt. To informanter sa det slik:

«Det var jo noen som ble litt kvalme.»

\section{«For mye sukker, olje og kremfløte, det ble for kvalmende for mange.» "Informant»}

«Det var ikke alltid det var vellykket. For mye sukker, olje og kremfløte, det ble for kvalmende for mange.»

\section{INDIVIDUELL TILPASNING}

\section{TILSETTING AV NARINGSSTOFFER}

Flere informanter påpekte at smoothien etter hvert ble tilpasset hver enkelt:

«I begynnelsen virker det veldig sånn fastlåst, og du skulle følge alt dette her. Du gjorde dine erfaringer, og det var jo ikke alle dette her [smoothien] falt i smak hos, det skulle vært litt 
mer lempelig.»

«For det var jo mange smoothieoppskrifter, og det er viktig å få i seg vitaminer, tenker jeg. Det trenger vi jo alle.»

Ifølge flere informanter ble ulike næringsstoffer tilsatt smoothien:

«Hvis bananene begynner å bli dårlige, så hiver vi oppi noe banan eller annen frukt, og hvis det er noe frukt vi har glemt en plass.»

« ... mye yoghurt, melk og fløte, juice og frossen frukt, og en del sukker og litt is.»

«Noen skulle ha eggeplommer óg i.»

\section{INDIVIDUELL MAT- OG DRIKKELISTE}

To av informantene påpekte at det var behov for individuelle mat- og drikkelister for å dokumentere hvilke næringsstoffer og hvor mange kalorier den enkelte fikk i seg:

«Det som jeg synes er litt vanskelig med dette, er at vi vet jo ikke hva de fikk i seg. Hvor mye kalorier, hvor mye energi og hvor mye næringsstoffer er det egentlig i dette vi holder på å gi dem, det visste vi ikke. Det hadde blitt noe helt annet hvis en skrev ned at i dag hadde en fått så og så mange milliliter av den typen.»

«Det ble jo ikke skrevet ned når du fulgte en oppskrift, men det er jo det som hadde vært interessant, for da kunne du sett resultatet. Hvis det sto hva du hadde gitt, så mye sukker, da betyr det at du ommøblerer rommet etterpå. Hvis du hadde så lite, så gikk det helt greit.»

\section{NOEN GÅR LEI AV SMOOTHIES}

Det var flere utsagn som viste at pasientene gikk lei av smoothies. Ved å redusere fra å ha det hver kveld til to dager i uka kunne det gi rom for variasjon. To av informantene sa det slik:

«Så opplever vi jo òg det at noen sier ?åh kommer du med den igjen nå?, så da tenkte jeg vi kan ikke ha det for ofte, vi må ha en pause.»

«Jeg tror de har vært lei av det, at det kanskje hadde vært bedre å ha hatt to ganger i uka så de ikke smaker det samme hele tiden.»

\section{NOEN LIKER SMOOTHIES}

Noen informanter ga uttrykk for at enkelte likte smoothies veldig godt. To utsagn eksemplifiserer dette:

«Noen ernæringsdrikker, de var så gode. Vi har en på 103, hun slikket glasset med fingeren.»

\section{«Noen ernæringsdrikker, de var så gode. Vi har en på 103, hun slikket glasset med fingeren.» «Informant»}

«Det var særlig én, hun skrøt sånn av at det var så godt. Hver kveld helst, det beste hun hadde smakt. Så tilbød vi jo henne litt mer da, hvis det var mer igjen, og ?ja takk, ja?.»

\section{MER FRUKT MED SMOOTHIES}

Det var usikkerhet blant informantene hvorvidt pasientene fikk i seg mer frukt med 
smoothien. Tre informanter sa det slik:

«I smoothien i stedet for i annen frukt, totalen blir den samme, for vi har alltid vært veldig opptatte av frukt og grønt.»

«... men jeg tror allikevel det er mer frukt i smoothien enn i frukten som de ville ha allikevel på kvelden.»

«Tror nok at de får i seg mer, for det er nok ikke alle som klarer å få i seg frukt.»

\section{DE UNDERERNARTE LA IKKE PÅ SEG}

Flere informanter hadde erfart at de som var underernærte, ikke la på seg. For å illustrere dette tar vi med følgende eksempler:

«[Det var] spennende om underernærte la på seg av smoothien, men det gjorde de ikke. Det er sykdommen sin gang.»

«Jeg kan ikke huske at vekten har forandret seg.»

«Hun som er 103-104, hun er dårligere, men det er jo på grunn av alder og mindre matlyst.»

\section{SMOOTHIES GIR ENERGI}

Flere av informantene mente at smoothies ga pasientene ekstra energi:

«Noen ble veldig på farten etter å ha fått smoothies, noen begynte å springe.»

«Det må være han som etter 20 minutter begynner å ommøblere. Det er ganske utrolig, synes jeg. Det slo ikke feil, etter 20 minutter begynte han å bli urolig, og etter en stund så fikk han andre ting, og da så vi at han roet seg, og vi fant jo ut grunnen til det. Det var så typisk 20 minutter etterpå.»

«[De burde] få smoothies på dagtid i plassen [for om kvelden og natten]. Det er jo energibombe, de ble mer aktive av at de fikk så mye energi.»

\section{DISKUSJON}

Hensikten med denne studien var å utforske hvilke erfaringer helsepersonell hadde med energirike smoothies til eldre pasienter i sykehjem. Det kom frem i analysen at ikke alle tålte smoothien. Enkelte fikk halsbrann, noen ble obstiperte, mens andre igjen ble kvalme. At enkelte fikk halsbrann, var forventet, da smoothien ble tilsatt juice, som kan gi sure oppstøt og en sviende smerte nederst i spiserøret $(5,22)$. Et interessant funn var at noen fikk obstipasjon. Når frukten og bærene blandes i blenderen, kuttes de i småbiter, og fibrene blir $\emptyset$ delagt (23), noe som øker risikoen for obstipasjon (13).

Ifølge tidligere forskning er det viktig at eldre får i seg nok fiber for å forebygge at de blir obstiperte $(24,25)$. Enkelte informanter løste dette med å gi frukt på dagtid. En annen måte å forebygge obstipasjon på, er å tilsette smoothien grønnsaker. Grønnsaker inneholder mer fiber som ikke blir ødelagt i blenderen, og som derfor gir økt tarmbevegelse og nærer de gode tarmbakteriene $(26,27)$.

\section{TILSETNINGER KAN GI KVALME}

Ifølge informantene ble smoothien ved noen anledninger tilsatt sukker, fløte og olje, som noen av informantene mente kunne gjøre pasientene kvalme. Denne antakelsen er i samsvar med en tidligere studie av pasienter med diabetes. Studien rapporterer at de som hadde 
forhøyet blodsukker, ble kvalme (28). Opplevelsen av kvalme kan også skyldes at eldre har nedsatt produksjon av gallesaft, lipase og fordøyelsesenzymer (29), som gir nedsatt fettoleranse og kvalme (30).

Det kom frem i analysene at de som var underernærte, ikke la på seg. Ifølge informantene kunne dette skyldes alderen, underliggende sykdommer eller nedsatt matlyst. For dem som har underliggende sykdom, eller som har nedsatt matlyst, kan det være aktuelt å tilføre næringsstoffer i smoothies etter individuelle behov $(9,31,32)$. Ut fra funnene i studien vår og tidligere studier $(9,31,32)$ er det viktig med individuell tilpasning av smoothien, slik at den enkelte får tilpasset sine behov for energi og næringsstoffer.

\section{VANSKELIG Å DOKUMENTERE NAERINGSINNTAK}

Enkelte informanter erfarte at smoothien ga energi, og at noen pasienter dermed ble aktive. Det var som forventet at noen ble aktive, da smoothien som ble gitt til pasientene, ble tilsatt sukker (10). På grunn av tilsettingen av sukker mente noen av informantene at pasientene heller måtte få smoothie på dagtid.

\section{«Enkelte informanter erfarte at smoothien ga energi, og at noen pasienter dermed ble aktive.»}

Videre påpekte også informantene at de syntes det var vanskelig å vite hva pasientene fikk i seg av næringsstoffer og væske når alt ble blandet sammen i blenderen og oppskriftene ikke alltid ble fulgt. Informantene $\emptyset$ nsket derfor at innholdet og mengden av smoothies som hver enkelt pasient inntok, ble registrert og dokumentert, slik at de fikk kontroll over hvor mye energi, næring og væske den enkelte pasienten fikk tilført. Å dokumentere mat og drikke er i tråd med nasjonale retningslinjer som skal sikre at sykehjemmene har systemer som dokumenterer pasientenes ernæringstilstand og risiko for underernæring $(1,5)$.

\section{KAN ØKE FRUKTINNTAKET}

Det er ulik oppfatning blant informantene om hvorvidt pasientene fikk i seg like mye eller mer frukt og bær under pilotprosjektet sammenliknet med før pilotprosjektet startet. Noen mente at pasientene fikk i seg mer frukt med smoothies, mens andre mente at de inntok like mye frukt som før pilotprosjektet startet. En tidligere studie (33) viser at 4 prosent av barna som spiste frokost, også spiste frukt, men når skolen tilbød smoothies, økte tilførselen av frukt til 45 prosent. Til tross for at studien (33) er gjennomført på skolebarn, kan det tenkes at resultatene fra studien kan ha overføringsverdi til eldre pasienter i sykehjem.

En annen studie viser også at de som har regelmessig tilgang til smoothies, lettere inntar nok frukt sammenliknet med dem som ikke får regelmessig tilgang til smoothies (15). Ut fra tidligere studier og funnene i denne studien er det grunn til å tro at pasientene fikk økt tilførsel av frukt i forbindelse med pilotprosjektet.

\section{STUDIENS STYRKER OG SVAKHETER}

En styrke ved studien vår er at vi valgte fokusgruppeintervjuer. Dermed kan erfaringer og meninger som deltakerne delte i gruppediskusjonene, bidra til nye refleksjoner og tanker som de kan overføre til egen praksis (20).

Intervjuer har en grunnutdanning i sykepleie og en videreutdanning i ernæring. Denne kompetansen gir kunnskap og forståelse når oppfølgingsspørsmål skal stilles (34). En begrensning kan være at denne forkunnskapen kan ha gitt forutinntatte holdninger og gjort intervjuer for lite nysgjerrig på deltakernes erfaringer når spørsmålene ble stilt (34). Intervjuer var bevisst på denne problematikken og tilstrebet at egne kunnskaper, 
opplevelser og erfaringer ikke skulle påvirke intervjusituasjonen, slik at informantene fikk fortelle fritt om sine erfaringer.

En svakhet med studien kan være at bare helsepersonell som jobbet dag og kveld, var med $\mathrm{i}$ studien. Årsaken er at det viste seg å være vanskelig å rekruttere deltakere som jobbet natt. To av fokusgruppene var homogene og besto av helsefagarbeidere, mens den ene var mindre homogen og besto av sykepleiere, vernepleier og helsefagarbeidere.

Noen anbefaler at fokusgrupper bør være homogene, da heterogene grupper der deltakerne har ulik utdanning og arbeidserfaring, kan føre til rangordning mellom deltakerne, noe som kan hemme diskusjonen i gruppa $(20,35)$. Ifølge Malterud (20) må derimot intensjonen om homogenitet balanseres mot variasjon i deltakerne, både innenfor hver gruppe og mellom samtlige deltakere, da mangfold i erfaringer kan skape nyanser i de empiriske dataene. I den ene gruppa, som besto av sykepleiere, vernepleier og helsefagarbeidere, var det to frafall. Det kan tenkes at opplevelse av rangordning kan være årsaken til frafallet.

\section{KONKLUSJON}

Hensikten med denne studien var å utforske helsepersonells erfaringer med energirike smoothies til eldre pasienter i sykehjem. Funnene viser at noen pasienter hadde problemer med ford $\varnothing$ yelsen med halsbrann, kvalme og forstoppelse. Videre kom det frem at de som var underernærte, ikke la på seg av smoothies, og at smoothies ga energi og førte til at noen ble overaktive. Individuell tilpasning av smoothies til eldre pasienter i sykehjem er nødvendig, slik at den enkeltes ønsker og behov kan bli ivaretatt. For å få kontroll over inntaket av væske, næringsstoffer og energi den enkelte pasienten får tilført gjennom smoothies, er det nødvendig med individuelle nærings- og drikkelister. ?

\section{REFERANSER}

1. Guthormsen A, Hensrud A, Irtun $\varnothing$, Mowé M, Sørby L, Thoresen L et al. Nasjonale faglige retningslinjer for forebygging og behandling av underernæring. Oslo: Helsedirektoratet; 2013. Tilgjengelig fra: https://helsedirektoratet.no/Lists/Publikasjoner/Attachments/916/Nasjonal-faglig-retningslinje-for-forebygging-og-behandling-av-underernering-I S-1580.pdf (nedlastet 17.08.2017).

2. Gammersvik ^̊ og Larsen T. Helsefremmende sykepleie - i teori og praksis. Bergen: Fagbokforlaget; 2012.

3. Mowé M. Behandling av underernæring hos eldre pasienter. Tidsskrift for Den norske legeforening 2002;122:815-8.

4. Mowé M, Bøhmer T. Reduced appetite. A predictor for undernutrition in aged people. J Nutr Health Aging 2002;6:81-3.

5. Arsky G, Arntzen R, Berg O, Bjørnstad E, Brantsæter A, Bye A et al. Kosthåndboken Veileder i ernæringsarbeid i helse- og omsorgstjenesten. Oslo: Helsedirektoratet, 2012. Tilgjengelig fra: https://helsedirektoratet.no/Lists/Publikasjoner/Attachments/51/Kosthaandboken-IS-1972.pdf\#page=3 (nedlastet 22.08.2016)

6. Helsedirektoratet. Ernæringskompetanse i helse- og omsorgssektoren. Oppdrag fra Helse og omsorgsdepartementet 2009-2012. Oslo: Helsedirektoratet, 2012. Tilgjengelig fra: https://helsedirektoratet.no/Lists/Publikasjoner/Attachments/41/Erneringskompetanse-i-helse-og-omsorgstjenesten-oppdrag-fra-helse-og-omsor gsdepartementet-2009-2012-IS-2032.pdf (nedlastet 01.09.2016).

7. Eide $\mathrm{H}$, Aukner $\mathrm{C}$, Iversen P. Nutritional status and duration of overnight fast among 
elderly residents in municipal nursing homes in Oslo. Vård i Norden 2012;32(1):20-4.

8. Mowé $\mathrm{M}, \mathrm{B} \emptyset \mathrm{hmer} \mathrm{T}$. Reduced appetite. A predictor for undernutrition in aged people. J Nutr Health Aging 2006;6:81-3.

9. Sortland K, Skjegstad G, Jansen L, Berglund A. Eldre personers ernæring og matinntak ved et sykehjem - en pilotstudie. Vård i Norden 2009;29:25-9.

10. Aagaard H. Mat og måltider i sykehjem. En nasjonal kartleggingsunders $\emptyset$ kelse. Sykepleien Forskning 2010;4:36-43. Tilgjengelig fra: https://sykepleien.no/forskning/2010/03/mat-og-maltider-i-sykehjem-en-nasjonal-kartleggingsundersokelse (nedlastet 17.08.2017).

11. Söderhamn U, Söderhamn O. A successful way for performing nutritional nursing assessment in older patients. J Clin Nurs 2009;18:431-9.

12. Leirvik $\AA$, Høye S, Kvigne K. Mat, måltider og ernæring på sykehjem - erfaringer fra et aksjonsforskningsprosjekt. Nordisk Sygeplejeforskning 2016;6:178-97.

13. Bondevik M, Nygaard H. Tverrfaglig geriatri. Bergen: Fagbokforlaget; 2012.

14. Mowé M. Kan ernæring forebygge eller dempe utvikling av Alzheimers sykdom? Demens \& Alderspsykiatri 2008;12:24-7.

15. Ruxton C. Smoothies: one portion or two? Nutr Bull 2008;33:129-32.

16. Lorefält B, Wilhelmsson S. A multifaceted intervention model can give a lasting improvement of older peoples nutritional status. The J Nutr Health and Aging 2012;16:378-82.

17. Crocker P. Juicing and smoothies for Dummies. Toronto: John Wiley and Sons; 2013.

18. Nilsson S. Nutritionshandbok för personal inom särskilt boende. Stockholm: Studentlitteratur; 2008.

19. St.meld. 34 (2012-2013): Folkehelsemeldingen: God helse - felles ansvar. Oslo: Helse- og omsorgsdepartementet; 2013. Tilgjengelig fra: https://www.regjeringen.no/contentassets/ce1343f7c56f4e74ab2f631885f9e22e/no/pdfs/stm201220130034000dddpdfs.pdf (nedlastet 01.09.2016).

20. Malterud K. Fokusgrupper som forskningsmetode for medisin og helsefag.Oslo: Universitetsforlaget; 2012.

21. Graneheim U, Lundman B. Qualitative content analysis in nursing research: concepts, procedures and measures to achieve trustworthiness. Nurs Educ Today 2004;24:105-12.

22. Drevon C, Blomhoff R. Mat og medisin. Kristiansand: Høyskoleforlaget; 2012.

23. Parada J, Aguilera J. Food microstructure affects the bioavailability of several nutrients. J Food Sci Nutr 2007;72:R21-32.

24. Cruz-Jentoft A, Calvo J, Duran J, Ordonez J, DeCastellar R. Compliance with an oral 
hyperproteic supplement with fibre in nursing home residents. J Nutr Health and Aging 2008;12:669-73.

25. Slavin J, Lloyd B. Health benefits of fruits and vegetables. Adv Nutr 2012;3:506-16.

26. Myskja A. Sannheten om mat. Oslo: J.M. Stenersens Forlag; 2012.

27. Svihus B. Spiselig - en fortelling om maten og mennesket. Oslo: Aschehoug; 2016.

28. Malik V, Popkin B, Bray G. Sugar-sweetened beverages and risk of metabolic syndrome and type 2 diabetes. Diabetes care 2010;33:2477-83.

29. Sortland K. Ernæring mer enn mat og drikke. Bergen: Fagbokforlaget; 2012.

30. Nes M, Müller H, Pedersen J. Ernæringslære. Oslo: Gyldendal Akademiske; 2006.

31. Manders M, de Groot C, Blauw Y, Dhonukshe-Rutten R, van Hoeckel-Prust L, Bindels $J$ et al. Effect of a nutrient-enriched drink on dietary intake and nutritional status in institutionalised elderly. Eur J Clin Nutr 2009;63:1241-50.

32. Allen V, Methven L, Gosney M. The influence of nutritional supplement drinks on providing adequate calorie and protein intake in older adults with dementia. J Nutr Health and Aging 2013;17:752-5.

33. Bates D, Price J. Impact of fruit smoothies on adolescent fruit consumption at school. Health Educ Behav 2015;42:487-92.

34. Malterud K. Kvalitative metoder i medisinsk forskning. Oslo: Universitetsforlaget; 2011.

35. Lerdal A, Karlson B. Bruk av fokusgruppeintervju. Sykepleien Forskning 2008;03:172-5. Tilgjengelig fra: https://sykepleien.no/forskning/2009/02/bruk-av-fokusgruppeintervju (nedlastet 17.08.2017). 